\title{
Çocuk Hemşirelerinin Terapötik Oyunu Kullanmaları ile Çocuk Sevme Durumları Arasındaki İlişkinin ve Etkileyen Faktörlerin İncelenmesi
}

\author{
Investigations of Relationship between Pediatric Nurses Use of Therapeutic Play and \\ Liking of Children and Affecting Factors
}

\author{
Ayşe Kahraman $^{1}$, Çisem Kırkan², Ali Aslan³, Havva Huyelmas³ ${ }^{3}$, Hatice Bal Yılmaz \\ ${ }^{1}$ Ege Üniversitesi Hemşirelik Fakültesi Çocuk Sağlığı ve Hastalıkları Hemşireliği Anabilim Dalı, Bornova / İzmir \\ ${ }^{2}$ Ege Üniversitesi Tip Fakültesi Çocuk Sağlığı ve Hastalıkları AD. Çocuk Acil Ünitesi, Bornova İzmir. \\ ${ }^{3}$ Ege Üniversitesi Sağlık Bilimleri Enstitüü̈ Çocuk Sağlı̆̆ı ve Hastalıkları Hemşireliği Anabilim Dalı, Bornova / İzmir \\ Yazıșma Adresi / Correspondence: \\ Ayşe Kahraman \\ Ege Üniversitesi Hemşirelik Fakültesi Çocuk Sağlığı ve Hastalıkları Hemşireliği Anabilim Dalı, İzmir \\ T: +902323115598Ｅ-mail : ayse.kahraman@ege.edu.tr \\ Geliş Tarihi / Received : 17.04.2020 Kabul Tarihi / Accepted : 02.07.2020 \\ Orcid : \\ Ayșe Kahraman https://orcid.org/ 0000-0001-7142-6592 \\ Çisem Kırkan https://orcid.org/ 0000-0002-3189-0531 \\ Ali Aslan https://orcid.org/ 0000-0003-3174-9017 \\ Havva Huyelmas https://orcid.org/ 0000-0003-2913-1904 \\ Hatice Bal Yllmaz https://orcid.org/ 0000-0001-8015-6379 \\ ( Sakarya Tip Dergisi / Sakarya Med J 2020, 10(3):365-372 ) DOI: 10.31832/smj.720565
}

Bu araștırma 27-30 Kasım 2019 tarihlerinde düzenlenen 2. Uluslararası 7. Ulusal Pediatri Hemşireliği Kongresinde sözel bildiri olarak sunulmuștur.

\footnotetext{
Öz

Amaç Hemșirelik bakımında terapötik oyunun kullanılması, çocuklarla bir bağ ve iletișim kurulmasına yardımcı olmaktadır. Bu araștırmanın amacı, çocuk hemșirelerinin terapötik oyunu kullanmaları ile çocuk sevme durumları arasındaki ilişkinin ve etkileyen faktörlerin incelenmesidir.

Gereç ve Kesitsel tanımlayıcı tipte araştırmada veriler 15.05.2019-20.07.2019 tarihleri arasında elde edilmiştir. Araştırmanın evrenini, bir çocuk hastanesinde çalıșan 178 hemşire,

Yöntem örneklemini ise çalışmaya katılmayı kabul eden 108 hemşire (\%60.6) oluşturmuştur. Araştırma verileri “Hemşire Tanıtım Formu”, "Çocuk Hemşirelerinin Terapötik Oyunu Kullanmasına Yönelik Bilgi Formu" ve "Barnett Çocuk Sevme Ölçeği” kullanılarak toplanmıștır.

Bulgular Calıșmaya katılan hemșirelerin yas ortalaması $31.50 \pm 2.60, \% 63.8$ 'i lisans mezunu, \%81.5' i kadın ve \%56.5' i 1-5 yll arasında çocuk servisinde çalısmaktadır. Hemșirelerin \%43.5’inin terapötik oyunu servislerde kullandığı, terapötik oyunu kullanmayan hemşirelerin \%53.6’sının zaman yetersizliği nedeniyle kullanmadıkları saptanmıștır. Çocuk hemşirelerinin ölçek toplam puan ortalamalarının $84.54 \pm 14.76$ olduğu belirlenmiştir. Terapötik oyunu kullanan hemşirelerin çocuk sevme ölçek puan ortalamalarının terapötik oyunu kullanmayan hemșirelere göre daha yüksek olduğu belirlenmiștir ( $\mathrm{p}=0.043)$.

Sonuç Çocuk hemșirelerinin terapötik oyunu servis ortamında yeterince kullanmadıkları, çocukları seven hemșirelerin terapötik oyunu daha fazla tercih ettikleri belirlenmiștir.

Anahtar Çocuk; Çocuk hemşireliği; Hastane; Çocuk sevme; Terapötik oyun.

Kelimeler

Abstract

Objective The use of therapeutic play in nursing care helps to establish a bond and communication with children. The aim of this study is to investigate the relationship between the use of therapeutic game of pediatric nurses and their liking of children.

Materials In the cross-sectional descriptive study, the data were obtained between 15.05.2019-20.07.2019. The population of the study consisted of 178 nurses working in a pediatric hospital. A total of

and methods 108 nurses (60.6\%) who accepted to participate in the study constituted the sample although it was aimed to reach the whole universe. The data were collected by using "Nurse Introduction Form", Bilgi Information Form for Pediatric Nurses to Use Therapeutic Play "and "Barnett Liking of Children Scale".

Results The mean age of the nurses participating in the study was $31.50 \pm 2.60,63.8 \%$ were undergraduate graduates, $81.5 \%$ were women and $56.5 \%$ were working in the pediatric service between 1-5 years. It was determined that $43.5 \%$ of the nurses use the therapeutic play in the clinics and $53.6 \%$ of the nurses who did not use the therapeutic play did not use it due to lack of time. The mean total score of pediatric nurses was found to be $84.54 \pm 14.76$. It was determined that the mean scores of child liking scale of nurses using therapeutic play were higher than nurses who did not use therapeutic play and the difference was significant $(p=0.043)$.

Conclusion It was determined that the pediatric nurses did not use the therapeutic game sufficiently in the clinical setting and the nurses who loved the children preferred the therapeutic game more.

Keywords Child; Pediatric nursing; Hospital; Liking of Child; Therapeutic Play.
} 


\section{GIIRIŞ}

Çocuklar gelişimleri boyunca akut veya kronik pek çok hastalık nedeniyle hastaneye yatabilmektedir. ${ }^{1,2}$ Çocuklarda hastaneye yatışa bağlı olarak korku, kaygı, ağrı, stres gibi olumsuz duygu durumları görülebilmekte ve bu olumsuz deneyimler karşısında çocuklar çeşitli tepkiler göstermektedir. ${ }^{1,3,4}$ Hastanede yatan çocuğun yaşadığı travmayı azaltmaya, çocuğun tanı ve tedavi işlemlerine ilişkin duygularını değerlendirmeye, durumu hakkında bilgilendirmeye, ameliyat öncesi, sırası ve sonrası dönemde stres, anksiyete ve ağrı yaratan durumlar ile olumlu baş etme yöntemleri geliştirmesine yardımcı yöntemler bulunmaktadır. Bunlardan en önemlisi terapötik oyundur., ${ }^{4,5}$

Terapötik oyun, Uluslararası Hemşirelik Girişimleri S1nıflamasına (NIC) göre, çocukların içinde bulundukları dünya ile ilgili algı ve bilgilerini iletmelerine, çevre hakkında bilgi ve kontrol kazanmalarına yardım etmek amacıyla oyuncakların ve diğer materyallerin amaç doğrultusunda yönlendirilmiş bir şekilde kullanılmasıdır. Yine Uluslararası Hemşirelik Girişimleri Sinıflamasına göre terapötik oyun bir hemşirelik girişimidir. ${ }^{6}$ Çocuk hemşireleri için terapötik oyun, çocuğu anlamada, hastaneye yatmaya hazırlamada, hastalık ve hastanenin etkilerini azaltmada önemli bir stratejidir. ${ }^{4}$ Terapötik oyun, çocukların hastaneye yatma ve uygulanacak girişimler hakkında duygu ve düşüncelerini sözel ya da sözel olmayan şekilde ifade etmesine olanak tanımaktadır. Çocuklarla çalışan hemşirelerin terapötik oyunu bakıma entegre etmek, oyun aracılığıyla topladığı bilgiler doğrultusunda hemşirelik bakımını sunmak gibi rol ve sorumluluklarının olduğu unutulmamalıdır., ${ }^{7,8}$

Hemşirelik bireyin bilgi, duygu ve düşüncelerini tanılayan ve bunları karşılamak için eylemlerde bulunan bir meslektir. ${ }^{9}$ Hemşirelerden mesleğini uygularken pek çok kişisel özellik beklenebilir. Bunlardan biri de sevgidir. ${ }^{10,11}$ Hayatın her döneminde olduğu gibi çocukluk döneminde de sevgi gereksinimi oldukça fazladır. ${ }^{12}$ Çocuğun akut veya kronik hastalık nedeniyle hastaneye yatması, sevgi ve ilgi gerek- siniminin karşılanmasını azaltabilmektedir. ${ }^{11}$ Hastanede yatmakta olan çocuğun sevgi ihtiyacı sağlık çalışanları ve özellikle çocuk hemşireleri aracılı̆̆ı̆la karşılanabilmektedir. ${ }^{11}$ Hemşirelerin çocuklara bakım verme ve onlarla birlikte bir şeyler yapabilme isteği çocukları sevme tutumuna bağlıdır. ${ }^{10}$

Ülkemizde her hemşire kendi istediği klinik alanda çalışamamaktadır. Çocukları sevmeyen hemşireler de çocuk servislerinde istihdam edilebilmektedir. ${ }^{10} \mathrm{Bu}$ durum verilen bakımın kalitesini, hemşirenin çocuk ile kurduğu iletişimi, atravmatik bakımda önemli bir yer tutan terapötik oyun kullanımını etkileyebilmektedir. Terapötik oyunun bakımda kullanılması ve yaygınlaştırılmasında aktif bir ajan olabilecek çocuk hemşirelerinin terapötik oyunu kullanmasında çocukları sevip sevmemesinin etkisinin bilinmesi önemlidir. Bu araştırmanın amacı, çocuk hemşirelerinin hastanede terapötik oyunu kullanmaları ile çocuk sevme durumları arasındaki ilişkinin ve etkileyen faktörlerin incelenmesidir.

\section{GEREÇ ve YÖNTEMLER}

Kesitsel tanımlayıcı tipte araştırmada veriler 15.05.201920.07.2019 tarihleri arasında elde edilmiştir. Araştırma İzmir ilinde bir çocuk hastanesinde yazılı izinler alındıktan sonra yürütülmüştür.

Araştırmanın evrenini, bir çocuk hastanesinde çalışan 178 hemşire oluşturmuştur. Evrendeki eleman sayısı bilindiğinden örneklem sayısı $n=\mathrm{Nt} 2 \mathrm{pq} / \mathrm{d} 2(\mathrm{~N}-1)+\mathrm{t} 2 \mathrm{pq}$ formülüyle hesaplanmıştır. Bu formüle göre örneklem sayısı 110 olarak belirlenmiştir. Çalışmaya katılmaya gönüllü olan 121 hemşireye ulaşılmıştır. Çalışmaya katılmaya gönüllü olmayan hemşireler araştırmaya dahil edilmemiştir. Veri toplama araçlarını eksik dolduran 13 hemşire çalışmadan çıkartılmış ve çalışmanın örneklemini 108 hemşire (\%60.6) oluşturmuştur. Araştırmayı yürütebilmek için iki ay süresince her hafta çocuk servislerine ziyaret gerçekleştirilmiştir. İlk ziyarette araştırmanın amacı açılandıktan sonra hemşirelerin anketleri doldurmaları istenmiştir. 
Hemşirelerde zaman baskısı yaratmamak adına bir sonraki gidişte anketler toplanmıştır. Hemşirelerin anketleri doldurması 5-6 dakika sürmüştür.

Araştırmanın bağımlı değişkeni; terapötik oyun oynama durumu, bağımsız değişkeni; çocuk servisinde çalışma yılı, çocuk sevme durumu, çocuk servisini isteyerek seçme durumu, çocuk servisini sevme durumu, terapötik oyun ile ilgili eğitim alma durumudur.

\section{Veri toplama Araçları}

Veriler "Hemşire Tanıtım Formu”, "Çocuk Hemşirelerinin Terapötik Oyunu Kullanmasına Yönelik Bilgi Formu” ve "Barnett Çocuk Sevme Ölçeği” kullanılarak elde edilmiştir. Hemşire Tanıtım Formu: Bu formda hemşirenin yaşı, cinsiyeti, eğitim durumu, hemşire olarak çalışma yılı, çocuk servisinde çalışma yılı, çocuk servisini isteyerek seçme durumu ve çocuk servisini sevme durumu, terapötik oyun ile ilgili eğitim alma durumunu içeren 9 soru yer almaktadır. Çocuk Hemşirelerinin Terapötik Oyunu Kullanmasına Yönelik Bilgi Formu: Bu form ilgili literatür kaynaklarından yararlanılarak hazırlanmıștır. ${ }^{7,8,13}$ Form, terapötik oyunun tanımı, amacı, serviste terapötik oyun oynama durumu, en çok oynanan oyun türü gibi 10 sorudan oluşmaktadır. Bilgi formunun kapsam geçerliliği için çocuk sağlığı ve hastalıkları hemşireliğinde uzman beş öğretim üyesinden uzman görüşü alınmıştır. Uzmanlardan ölçek maddelerini (4) "Uygun”, (3) "Madde hafifçe gözden geçirilmeli", (2) "Madde ciddi olarak gözden geçirilmeli” ve (1) "Madde uygun değil" şeklinde dörtlü derecelendirmektedir. Uzman görüşlerinin değerlendirmesinde Kapsam geçerlilik indeksi kullanılmıştır. ${ }^{14}$ Kapsam geçerlilik indeksi 0.80 olarak belirlenmiştir. Uzman görüşlerine göre bilgi formu düzenlenmiş ve son şekli verilmiştir.

Barnett Çocuk Sevme Ölçeği: Ölçek Barnett ve Sinisi tarafından geliştirilmiş, insanların çocukları sevip sevmediklerini değerlendiren 14 sorudan oluşan 1-7 puan arasında puanlanan likert türü bir ölçektir. ${ }^{15}$ Çocukları sevme düzeyini saptamaya yönelik maddelerden onu olumlu, dördü olumsuz anlam taşımaktadır. Olumlu maddelerde “Tamamen katılıyorum" yanıtı " 7 " ile ve "Hiç katılmıyorum" yanıtı ise "1" ile, Olumsuz maddelerde "Hiç katılmıyorum" yanıtı "7" ile "Tamamen katılıorum" yanıtı da " 1 " ile puanlanmaktadır. Ölçekten yüksek puan alan kişilerin çocuk sevme düzeyinin yüksek olduğu; düşük puan alanların ise çocuk sevme düzeyinin düşük olduğu şeklinde yorumlanır. Ölçeğin Türkçe geçerlik ve güvenirliği Duyan ve Gelbal tarafından yapılmış, Cronbach alfa değeri 0.92 olarak belirlenmiştir. Ölçekten alınan 14-38 puanı düşük, 39-74 puanı orta, 75-98 puanı yüksek çocuk sevme puanı olarak belirtilmiştir. ${ }^{16}$ Ölçeğin kullanımı için Gelbal'dan e-posta yoluyla izin alınmıştır. Bu çalışmada ölçeğin Cronbach alfa katsayısı 0.94 olarak belirlenmiştir.

\section{Araştırmanın Etik Yönü}

Araştırmanın yapılabilmesi için Ege Üniversitesi Tıbbi Araştırmalar Etik Kurulundan (E.123792, Onay tarihi: 18.04.2019) ve çalışmanın yapılacağı kurumdan (E.107426, Onay tarihi: 04.04.2019) yazılı izin alınmıştır. Tüm hemşirelere çalışmanın amacı açıklanıp, sözlü ve yazılı onamları alınmıştır. Çalışma Helsinki Deklarasyonu Prensipleri’ne uygun olarak yapılmıştır.

\section{Verilerin Değerlendirilmesi}

Verilerin analizi SPSS 22.0 paket programında gerçekleştirilmiştir. Verilerin normal dağılıma uygunluk kontrolünde Kolmogorov Smirnov testi kullanılmıştır. Elde edilen verilerin dağılımlarının karşılaştırılmasında tanımlayıcı istatistik testleri (sayı, yüzde, standart sapma, ortalama), normal dağılan değişkenlerin karşılaştırmalarında t test, normal dağılmayan değişkenlerin karşılaştırmalarında Mann-Whitney U test kullanılmıştır. Hemşirelerin terapötik oyunu kullanması ile çocuk sevme durumu arasındaki ilişki regresyon analizi ile incelenmiştir. Tüm bulgular \%95 güven aralığında ve $\mathrm{p}<0.05$ üzerinden değerlendirilmiştir.

\section{BULGULAR}

Hemşirelerin yaş ortalaması $31.50 \pm 2.60$, \%63.8'i lisans mezunu, \%81.5’i kadın ve \%56.5’i 1-5 yıl arasında çocuk 
servisinde çalışmaktadır. Hemşire başına düşen hasta sayısının 10.64 \pm 16.13 olduğu belirlenmiştir (Tablo 1).

Hemşirelerin \%33.1'i çocuğun stres ve anksiyetesini azaltmak için işlemi anneye anlattığını, \%32.6'sı ailenin yardımını aldığını belirtmiştir. Hemşirelerin \%65’i terapötik oyunun amacının hasta çocuğun hastanede yapılan işlemlerle ilgili duygu ve düşüncelerini açıklamasına yardımcı olduğunu, \%23.8'i çocuğun bebek/ kuklaları ile onlara hasta/ doktor rolü vererek oynamasını sağladığı saptanmıştır. Hemşirelerin \%43.5'inin servis ortamında terapötik oyunu kullandığı, \% 45.1'i terapötik oyunda intravenöz set, enjektör ve nazogastrik tüpleri kullandığı, \%34’ünün aşırı anksiyete/korku içinde olan çocuklarda terapötik oyunu kullandığı belirlenmiştir. Terapötik oyunu kullanmayan hemşirelerin \%53.6'sının zaman yetersizliği nedeniyle kullanmadıkları saptanmıştır (Tablo 2).

Çocuk hemşirelerinin çocuk sevme ölçek toplam puan ortalamalarının $84.54 \pm 14.76$ olduğu belirlenmiştir. Hemşirelerin cinsiyet, hemşire olarak çalışma yılı, çocuk servisinde çalışma yılı, çocuk servisini isteyerek seçme durumu ile çocuk sevme ölçeği toplam puanları arasında fark saptanmamıştır ( $\mathrm{p}>0.05)$. Çocuk servisinde severek çalışan hemşirelerin çocuk sevme ölçeği toplam puanlarının daha yüksek olduğu saptanmıştır ( $\mathrm{p}=0.025)$ (Tablo 3). Terapötik oyunu kullanan hemşirelerin çocuk sevme ölçek puan ortalamalarının terapötik oyunu kullanmayan hemşirelere göre daha yüksek olduğu belirlenmiştir $(p=0.043)$ (Tablo 3).
Tablo 1: Çocuk hemşirelerinin sosyodemografik özellikleri ve mesleki deneyimlerine göre dağılımı

\begin{tabular}{|l|c|c|}
\hline Sosyo-demografik Özellikler & $\begin{array}{c}\text { Frekans } \\
(\mathbf{n})\end{array}$ & $\begin{array}{c}\text { Yüzd } \\
(\%)\end{array}$ \\
\hline
\end{tabular}

Yaş

\begin{tabular}{|l|l|l|}
\hline $21-25$ yaş arası & 34 & 31.5 \\
\hline $26-30$ yaş arası & 28 & 25.9 \\
\hline $31-35$ yaş arası & 15 & 13.9 \\
\hline $36-40$ yaş arası & 16 & 14.8 \\
\hline 41 yaş ve üzeri & 15 & 13.9 \\
\hline
\end{tabular}

\begin{tabular}{|l|c|c|}
\hline Cinsiyet & \multicolumn{3}{|l|}{} \\
\hline Kadın & 88 & 81.5 \\
\hline
\end{tabular}

\begin{tabular}{|l|l|l|}
\hline Erkek & 88 & 81.5 \\
\hline
\end{tabular}

Eğitim

\begin{tabular}{|l|l|l|}
\hline Lise & 12 & 11.1 \\
\hline Önlisans & 11 & 10.2 \\
\hline Lisans & 69 & 63.8 \\
\hline Lisansüstü & 16 & 14.9 \\
\hline
\end{tabular}

Çocuk Servisinde Çalıșma Yılı

\begin{tabular}{|l|c|c|}
\hline $1-5$ y1l & 61 & 56.5 \\
\hline $6-10$ yll & 20 & 18.5 \\
\hline $11-15$ yll & 16 & 14.8 \\
\hline $16-20$ yll & 8 & 7.4 \\
\hline 20 yll üzeri & 3 & 2.8 \\
\hline
\end{tabular}

Çalıșılan Birim

\begin{tabular}{|l|c|c|}
\hline Genel Pediatri & 15 & 13.9 \\
\hline Çocuk yoğun bakım ünitesi & 38 & 35.2 \\
\hline Çocuk acil servisi & 12 & 11.1 \\
\hline Hematoloji & 15 & 13.9 \\
\hline Nöroloji & 16 & 14.8 \\
\hline $\begin{array}{l}\text { Diğer servisler (Kardiyoloji, Nefroloji, } \\
\text { Gastroenteroloji, Endokrin) }\end{array}$ & 12 & 11.1 \\
\hline
\end{tabular}

Çocuk servisini isteyerek seçme

\begin{tabular}{|l|c|c|}
\hline Evet & 26 & 24.1 \\
\hline Hayır & 82 & 75.9 \\
\hline Çocuk servisini sevme & 100 & 92.6 \\
\hline Evet & 8 & 7.4 \\
\hline Hayır & 12 & 11.1 \\
\hline Terapötik Oyun İle İlgili Eğitim Alma Durumu \\
\hline Evet & 96 & 88.9 \\
\hline Hayır & 108 & 100 \\
\hline Toplam & &
\end{tabular}


Sakarya Tip Dergisi 2020;10(3):365-372

KAHRAMAN ve Ark., Hastanede Terapötik Oyun Oynama ve Çocukları Sevme

\begin{tabular}{|c|c|c|}
\hline Sosyo-demografik Özellikler & $\begin{array}{l}\text { Frekans } \\
\qquad(\mathbf{n})\end{array}$ & $\begin{array}{c}\text { Yüzde } \\
(\%)\end{array}$ \\
\hline \multicolumn{3}{|c|}{ Çocuğun anksiyetesini azaltmak için yapılan uygulamalar ${ }^{\star}$} \\
\hline İşlemi anneye anlatmak & 58 & 33.1 \\
\hline Çocukla terapötik oyun oynamak & 43 & 24.6 \\
\hline İşlemi zorla uygulamak & 9 & 5.1 \\
\hline Ailenin yardımını almak & 57 & 32.6 \\
\hline Herhangi bir işlem yapmıyorum & 8 & 4.6 \\
\hline \multicolumn{3}{|l|}{ Hastanede terapötik oyununun amacı* } \\
\hline Hastane ortamında eğlenmesi & 33 & 23.1 \\
\hline $\begin{array}{l}\text { Hastanede yapılan işlemlerle ilgili duygu ve } \\
\text { düşüncelerini açıklaması }\end{array}$ & 93 & 65.0 \\
\hline $\begin{array}{l}\text { Hasta çocukların birbirleri ile iletişim } \\
\text { sağlaması }\end{array}$ & 17 & 11.9 \\
\hline \multicolumn{3}{|l|}{ Hastanede terapötik oyunun işlevi* } \\
\hline Çocuk-hemşire arasında iletişim aracı & 57 & 31.7 \\
\hline Zaman geçirme yöntemi & 18 & 10 \\
\hline $\begin{array}{l}\text { Hemşirelerin işlerini kolaylaştıran bir } \\
\text { yöntem }\end{array}$ & 42 & 23.3 \\
\hline Çocukların kendini ifade etme yöntemi & 63 & 35 \\
\hline \multicolumn{3}{|c|}{$\begin{array}{l}\text { Hemşirenin çocuğun terapötik oyun oynaması hakkındaki } \\
\text { düşüncesi* }\end{array}$} \\
\hline Her zaman oynanmalı & 68 & 36.8 \\
\hline Bir faydası olduğunu düşünmüyorum & 11 & 5.9 \\
\hline $\begin{array}{l}\text { Hemşire - çocuk arasındaki iletişimi artırıp } \\
\text { tedavi uygulamasına yardımcı oluyor }\end{array}$ & 57 & 30.8 \\
\hline $\begin{array}{l}\text { Çocuğun anksiyetesini azaltmaya çok } \\
\text { büyük katkısı var }\end{array}$ & 49 & 26.5 \\
\hline \multicolumn{3}{|l|}{ Terapötik oyun türü* } \\
\hline $\begin{array}{l}\text { Çocuğun tıbbi cihaza dokunmasına ve } \\
\text { oynamasına izin vermek (steteskop, tansi- } \\
\text { yon aleti ateş ölçer, enjektör, serum seti vb.) }\end{array}$ & 47 & 18.1 \\
\hline $\begin{array}{l}\text { Çocuğun müzik dinlemesine izin vermek } \\
\text { ve önermek }\end{array}$ & 43 & 16.5 \\
\hline $\begin{array}{l}\text { Çocuğun resim yapması için yönlendirmek } \\
\text { ve ortam sağlamak }\end{array}$ & 54 & 20.8 \\
\hline $\begin{array}{l}\text { Çocuğun müzik ile oynamasına ortam } \\
\text { oluşturmak ve izin vermek }\end{array}$ & 38 & 14.6 \\
\hline $\begin{array}{l}\text { Çocuğun bebek/ kuklaları ile onlara hasta/ } \\
\text { doktor rolü vererek oynamasını sağlamak }\end{array}$ & 62 & 23.8 \\
\hline $\begin{array}{l}\text { Çocuğa mektup yazdırmak, günlük tut- } \\
\text { turmak }\end{array}$ & 16 & 6.2 \\
\hline \multicolumn{3}{|l|}{ Terapötik oyun gerekliliği* } \\
\hline Evet & 72 & 66.7 \\
\hline Hayır & 3 & 3.8 \\
\hline Bazen & 33 & 30.6 \\
\hline
\end{tabular}

\begin{tabular}{|c|c|c|}
\hline Sosyo-demografik Özellikler & $\begin{array}{l}\text { Frekans } \\
\quad(\mathbf{n})\end{array}$ & $\begin{array}{l}\text { Yüzde } \\
(\%)\end{array}$ \\
\hline \multicolumn{3}{|l|}{ Terapötik oyun oynama durumu } \\
\hline Evet & 47 & 43.5 \\
\hline Hayır & 61 & 56.5 \\
\hline \multicolumn{3}{|l|}{ En çok kullandığı terapötik oyun* } \\
\hline Kil ya da oyun hamuru ile oynamak & 7 & 5.7 \\
\hline $\begin{array}{l}\text { İntravenöz set, enjektör, nazogastrik tüpler- } \\
\text { le oynamak }\end{array}$ & 55 & 45.1 \\
\hline Müzik aletleri ile oynamak & 21 & 17.2 \\
\hline Resim çizdirmek & 39 & 32 \\
\hline \multicolumn{3}{|l|}{ Terapötik oyunu kullandıkları durumlar* } \\
\hline Tedaviye uyumu olmayan çocuklarda & 46 & 21.7 \\
\hline $\begin{array}{l}\text { Aşırı anksiyete/ korku içinde olan çocuk- } \\
\text { larda }\end{array}$ & 72 & 34.0 \\
\hline İnvaziv girişimlerde & 43 & 20.2 \\
\hline İletişim kurmak istemeyen çocuklarda & 33 & 15.6 \\
\hline Oyun oynamayı seven çocuklarda & 18 & 8.5 \\
\hline \multicolumn{3}{|l|}{ Oynamama nedeni } \\
\hline Zaman yetersizliği & 33 & 53.6 \\
\hline Hasta sayısının fazlalığı & 22 & 35.7 \\
\hline $\begin{array}{l}\text { Hemşirenin iş ortamında yeterli isteği } \\
\text { bulamaması }\end{array}$ & 6 & 10.7 \\
\hline \multicolumn{3}{|c|}{$\begin{array}{l}\text { * Hemşireler bir soruya birden fazla yanıt verdiği için n sayısı } \\
\text { katlanmıştır. }\end{array}$} \\
\hline
\end{tabular}

Tablo 3. Çocuk hemşirelerinin terapötik oyunu kullanması ile çocuk sevme durumu arasındaki ilişkinin ve etkileyen bazı değişkenlerin karşılaştırılması

\begin{tabular}{|l|c|c|}
\hline \multirow{2}{*}{ Değişkenler } & \multicolumn{2}{c|}{$\begin{array}{c}\text { Barnett Ölçek Toplam Puan } \\
\text { Ortalaması }\end{array}$} \\
\cline { 2 - 3 } Terapötik oyun oynama durumu & İstatistiksel Değer \\
\hline Evet & $87.80 \pm 13.50$ & $\mathrm{~F}=4.183$ \\
\hline Hayır & $82.03 \pm 15.30$ & $\mathrm{p}=0.043$ \\
\hline Çocuk servisini sevme & $85.44 \pm 14.68$ & $\mathrm{t}=2.267$ \\
\hline Evet & $73.37 \pm 11.38$ & $\mathrm{p}=0.025$ \\
\hline Hayır & $85.58 \pm 9.51$ & $\mathrm{t}=0.257$ \\
\hline Terapötik oyun konusunda eğitim alma \\
\hline Evet & $84.41 \pm 15.32$ & $\mathrm{p}=0.798$ \\
\hline Hayır & \multicolumn{2}{|c|}{} \\
\hline X: Ortalama, SS: Standart Sapma, F: regresyon analizi \\
\hline
\end{tabular}




\section{TARTIŞMA}

Hemşirelik bakımında oyunun kullanımı modern hemşireliğin kurucusu Florence Nightingale tarafından vurgulanan bir girişimdir. Çocuk hemşirelerinin çocuk bakımında oyuncakları nasıl kullanacaklarını bilmeleri ve onları fiziksel bakım sırasında kullanma şekilleri oldukça önemlidir. ${ }^{17,18}$ Hemşirelik bakımında terapötik oyunun kullanılması, çocuklarla bir bağ ve iletişim kurulmasına yardımcı olmaktadır. Oyun, hemşireye çocuğun duyguları ve kaygıları ile ilgili bilgi vermekte, çocuğun stres ve kaygılarını hafifletmektedir. ${ }^{17,19}$ Hemşirelerin hastanede yatan çocukların günlük rutin bakımı sırasında, ameliyat ve invaziv prosedürlerde, ağrılı ve rahatsız edici prosedürlere hazırlama aşamasında terapötik oyunu bir bakım stratejisi olarak kullanabileceği bildirilmektedir. ${ }^{17,18,20,21}$

Araştırmada, hemşirelerin çoğunluğu terapötik oyunun hasta çocuğun hastanede yapılan işlemlerle ilgili duygu ve düşüncelerini açıklamasına yardımcı olduğunu ve terapötik oyunun servislerde gerekli olduğunu belirttiği fakat yarısından fazlasının terapötik oyunu kullanmadığ belirlenmiştir. Literatürde benzer sonuçların olduğu göze çarpmaktadır. ${ }^{13,20,22,23}$ Yapılan bir çalışmada, hemşirelerin \%83.3'ü çocuğun hastanede anksiyetesini azaltmak için terapötik oyunu uyguladığını ve \%59.5'inin fazla sayıda hasta olduğu için terapötik oyunu ara sıra uyguladığı saptanmıştır. ${ }^{13}$ Francischinelli ve arkadaşlarının çalışmasında hemşirelerin \%29.9’u terapötik oyunun geçerli bir uygulama olduğunu fakat \%18.6’inin çalıştıkları birimlerde kullanmadıkları belirlenmiştir. ${ }^{23}$ Yapılan çalışmalarda, hemşirelerin terapötik oyunu bakıma katkı sağlayan en önemli girişimlerden biri olarak gördükleri ve terapötik oyunu bakımda kullanmak istedikleri vurgulanmaktadır. ${ }^{18,23}$ Hemşirelerin terapötik oyunu kullanmasında en önemli engelin zaman yetersizliği olduğu belirtilmektedir. ${ }^{18} \mathrm{Bu}$ araştırmada da hemşirelerin terapötik oyun oynamama nedeni zaman yetersizliği olarak belirlenmiştir. İnci ve Günay’ın çalışmasında hemşirelerin hasta sayısının fazlalığı (\%59.5) ve zaman yetersizliği (\%42.0) nedenleriyle terapötik oyunu kullanamadıkları veya ara sıra kullandık- ları saptanmıştır. ${ }^{13}$ Hemşirelerin iş yükünün ve klinikteki hasta sayısının fazla olması hemşirelik bakım kalitesini olumsuz olarak etkileyebilmektedir. Hemşirelerin zaman yetersizliği nedeniyle çocuklara yeterli zaman ayıramamasının bakımda terapötik oyunu kullanma durumunu olumsuz etkilediği düşünülmektedir. Halbuki hastane ortamında rutin prosedürler sirasında olumsuz deneyimlere ve kısıtlamalara maruz kalan çocukların yaşadıkları korku ve kaygı ile prosedürlerin süreleri ve hastanede tedavi ve bakım süreçleri uzamakta, başarılı prosedürlerin sayısı azalmaktadır. Çocukların hastaneye ve hastalığa tepkileri iyileşmenin kabulünü de engellemektedir. Bu nedenlerle, Uluslararası Hemşirelik Girişimleri Sınıflamasına göre hemşirelik girişimlerinden biri olan terapötik oyunu pediatri hemşirelerinin bakımın her aşamasına entegre etmeleri gerekliliği unutulmamalıdır.

Çocuklarla çalışan hemşirelerin çocukları sevme, çocuklarla iyi ilişkiler kurabilme ve ilgili olma gibi özelliklere sahip olması önemlidir. ${ }^{11}$ Çocuk servisinde çalışan hemşirelerin çocuk sevme durumlarının incelendiği üç çalışmada, çocuk sevme düzeylerinin yüksek olduğu vurgulanmıştır. ${ }^{10,24,25}$ Benzer şekilde bu araştırmada da, çocuk hemşirelerinin çocuk sevme düzeylerinin yüksek olduğu belirlenmiştir.

Araştırmada çocuk servisinde severek çalışan hemşirelerin çocukları daha çok sevdikleri belirlenmiştir. Hemşirelerin çocuk hemşiresi olmak ve çocuk servisinde çalışmak istemesindeki en büyük etken çocukları sevmeleridir. ${ }^{11}$ Bununla birlikte ülkemizde çeşitli nedenlerden dolayı hemşireler severek çalışacakları klinik alanda çalışamamaktadır. Sıklıkla hemşire gereksinimi olan kliniklerde istihdam edilebilmektedir. Hemşireler kendi isteği dışında klinik değişikliği yapabilmekte ve çalışmak istemedikleri alanlarda uzun yıllar kalabilmektedirler. Hemşirelerin sevmediği ve çalışmak istemediği kliniklerde çalışmaları onları her açıdan olumsuz yönde etkilemektedir. ${ }^{10,26}$

Çalışmada, terapötik oyunu kullanan hemşirelerin çocuk 
sevme ölçek puan ortalamalarının terapötik oyunu kullanmayan hemşirelere göre daha yüksek olduğu belirlenmiştir. Çocukları seven ve çocuk servisinde severek çalışan hemşirelerin, çocukların bakım uygulamalarından, ağrılı ve rahatsız edici prosedürlerden daha az etkilenmesini sağlamak için girişimler planlayabildiği ve bu girişimlerden biri olan terapötik oyunu kullanabildiği düşünülmüştür.

Sonuç olarak, çocuk hemşirelerinin terapötik oyunun çocuk servisilerinde çocuk hasta ve ailelerinde yarattığı etkinin farkında olması ve günlük bakımlarında terapötik oyunun önemine inanması gerekmektedir. Hemşireler, çocukların korku ve anksiyetelerinin azaltılması ve duygularını yansıtabilmeleri için terapötik oyunun bakıma dahil edilmesi konusunda duyarlı olmalıdır. Hemşirelerin terapötik oyun konusunda farkındalıklarının arttırılması, çocukları seven hemşirelerin çocuk servislerinde çalışması ve hemşirelerin terapötik oyuna zaman ayrılması önerilmektedir.

\section{Çalışmanın Kısıtlılığı}

Araştırmanın bazı sınırlılıkları mevcuttur. Bu çalışma izin alınabilen bir hastanede yürütülmüştür. Tüm hemşireler gönüllü olmadığından, gönüllü olup veri toplama araçlarını eksik dolduran hemşireler çalışmadan çıkartıldığından tüm evrene ulaşılamamıştır. Çalışmanın tek bir hastanede yürütülmesi ve katılımcı sayısının az olması sınırlılıkları oluşturmaktadır. İleride daha geniş örneklemlere ulaşıması önerilmektedir.

\section{Çıkar Çatışması}

Yazarlar çıkar çatışması bildirmemiştir.

\section{Etik onay}

Çalışmanın yapılabilmesi için Ege Üniversitesi Tibbi Araştırmalar Etik Kurulundan (E.123792, Onay tarihi: 18.04.2019) ve araştırmanın yapıldığı kurumdan (E.107426, Onay tarihi: 04.04.2019) yazılı izin alınmıştır. 
Sakarya Tip Dergisi 2020;10(3):365-372

KAHRAMAN ve Ark., Hastanede Terapötik Oyun Oynama ve Çocukları Sevme

\section{Kaynaklar}

1. Yayan EH, Zengin M. Çocuk kliniklerinde terapötik oyun. GÜSBD 2018; 7(1):226-233.

2. Gültekin G, Baran G. Hastalık ve çocuk. Aile ve Toplum 2005; 2(9):61-68.

3. Lerwick JL. Psychosocial implications of pediatric surgical hospitalization. Semin Pediatr Surg 2013; 22(3):129-133. doi: 10.1053/j.sempedsurg.2013.04.003.

4. Cimete G, Kuğuoğlu S, Dede Çınar N. Çocuk, hastalık ve hastane ortamı, İçinde: Conk Z.,Başbakkal Z, Bal Yılmaz H, Bolşsılk B. (Ed.). Pediatri Hemşsireliği, 3. Bölüm, Akademisyen Tip Kitabevi, Ankara, 2018; 101-160.

5. Li HCW, Lopez V. Effectiveness and appropriateness of therapeutic play intervention in preparing children for surgery: A randomized controlled trial study. J Spec Pediatr Nurs 2008; 13(2): 63-73. doi: 10.1111/j.1744-6155.2008.00138.x.

6. Bulechek GM, Butcher HK, Dochterman JM, Wagner C. Hemșirelik Girișimleri Sinıflaması (NIC). 6. Baskı, İstanbul. Nobel Tip Kitabevleri, 2017, s.357.

7. İnal S, Akgün M. Hastanede yatan çocukta terapötik iletișim. Atatürk Üniversitesi Hemșirelik Yüksekokulu Dergisi 2003; 6(2):67-76.

8. Kıran B, Çalık C, Esenay FI. Terapötik oyun: hasta çocuk ile iletişimin anahtarı, Ankara Sağllk Bilimleri Dergisi 2013; 2(1-2-3):1-10.

9. Arslan Özkan H, Bilgin Z. Hemşireliğin felsefi özü iyileștirici bakım. HSP 2016; 3(3):191200. doi: 10.17681/hsp.49209

10. Büyük ET, Rizalar S, Seferoğlu EG, Oğuzhan H. Çocuk ve erişkin kliniklerinde çalışan hemşirelerin çocuk sevme ve çocuk yetiştirme tutumlarınin incelenmesi, J Pediatr Res 2014;1(3):130-7. Doi: 10.4274/jpr.32032

11. Çavuşoğlu H. Çocuk Sağlığı Hemşireliği. Genişletilmiş 11. Baskı. Ankara: Sistem Ofset Bastmevi; 2012; 1-31:51-69.

12. Bektaş M, Ayar D, Bektaş İ, Selekoğlu Y, Kudubeș AA, Altan, SS. Hemşirelik öğrencilerinin çocuk sevme durumların etkileyen faktörlerin belirlenmesi. J Pediatr Res 2015; 2(1):37-41. Doi: $10.4274 /$ jpr. 47966

13. İnci $R$, Günay $U$. Pediatri hemşirelerinin terapötik oyuna yönelik bilgi, görüş ve uygulamalarl, ACU Sağlk Bil Derg 2019; 10(3):547-551. Doi: 10.31067/0.2019.187

14. Polit $D$ \& Beck $C$. The content validity index: are you sure you know what's being reported? critique and recommendations. Res Nurs Health. 2006; 29, 489-497. Doi: 10.1002/ nur.20147

15. Barnett MA, Sinisi CS. The initial validation of a liking of children scale. Journal of Personality Assessment 1990; 55(1-2):161-7. Doi: 10.1080/00223891.1990.9674055

16. Duyan V, Gelbal S. Barnett Çocuk Sevme Ölçeğini türkçeye uyarlama çalıșması. Eğitim ve Bilim Dergisi 2008; 33(148):40-8.

17. Büyük ET, Bolşsık B. The effect of preoperative training and therapeutic play on children's anxiety, fear and pain. Journal of Pediatric Surgical Nursing 2015; 4(2):78-85.

18. Maia EB, Ribeiro CA, de Borba RI. Understanding nurses' awareness as to the use of therapeutic play in child care. Rev Esc Enferm USP 2011; 45(4):839-46. Doi: 10.1590/s008062342011000400007

19. Caleffi CCF, Rocha PK, Anders JC, Souza AIJ, Burciaga VB, Serapiao LS. Contribution of structured therapeutic play in a nursing care model for hospitalised children. Rev Gaucha Enferm 2016; 37(2):e58131. doi: 10.1590/1983-1447.2016.02.58131.

20. Koukourikos K, Tzeha L, Pantelidou P, \& Tsaloglidou A. The importance of play during hospitalization of children. Materia Socio Medica 2015; 27(6),438. doi: 10.5455/ msm.2015.27.438-441.

21. Haiat H, Bar-Mor G, Shochat M. The world of the child: a World of play even in the hospital. J Pediatr Nurs 2003;18(3):209-14. Doi: 10.1053/jpdn.2003.28

22. Oliveira CS, Maia EBS, Borba RIH, Ribeiro Brinquedo Terapêutico na assistência à criança: percepção de enfermeiros das unidades pediátricas de um hospital universitário. Rev. Soc. Bras. Enferm. Ped. 2015; 15(1): p 21-30

23. Francischinelli AGB, Almeida FA, Fernandes DMSO. Routine use of therapeutic play in the care of hospitalized children: nurses' perceptions, Acta Paul Enferm 2012;25(1):18-23. Doi: 10.1590/S0103-21002012000100004

24. Erdem Y, Duyan V. A determination of the factors that affect the level of pediatric nurses' liking of children. Turk J Med Sci 2011; 41(2):295-305. Doi: 10.3906/sag-1003-700

25. Kostak MA, Semerci R, Kocaaslan EN. Hemşirelerin çocuk sevme düzeyleri ve çocuk yetiştirme tutumlart. GÜSBD 2017; 6(4):146-55.

26. Tan M, Polat H, Akgün Şahin Z. Hemşirelerin çalıșma ortamlarına ilişkin algılarının değerlendirilmesi. Sağllkta Performans ve Kalite Dergisi 2012; 4:67-78. 